\title{
Leaching of Potentially Toxic Metals (PTMs) from Two Nigerian Clays and Related Clay Pottery Used Locally as Foodwares
}

\section{Ndokiari Boisa* and Deeue Bekee}

Department of Chemistry, Rivers State University, Port Harcourt, Nigeria

*Corresponding author: Ndokiari Boisa, Department of Chemistry, Rivers State University, Port Harcourt, Nigeria, Tel: +2348064328181; E-mail: boisa.ndokiari@ust.edu.ng

Received date: November 01, 2017; Accepted date: November 07, 2017; Published date: November 27, 2017

Copyright: (c) 2017 Boisa N, et al. This is an open-access article distributed under the terms of the Creative Commons Attribution License, which permits unrestricted use, distribution, and reproduction in any medium, provided the original author and source are credited.

\begin{abstract}
There is presently lack of data on composition of potentially toxic metals and their leaching from clay based foodwares into food. Therefore, in present study we evaluated the leaching of cadmium, chromium, copper, manganese, nickel, lead and zinc from raw clays and traditional clay pots from two locations, Ara-Ekiti, Ekiti State and Kono-Boue, Rivers State in Nigeria. Samples were digested with aqua regia and analysed using atomic absorption spectrometry and also with energy dispersive $\mathrm{X}$-ray fluorescence. Tap water set at different temperatures $\left(27^{\circ} \mathrm{C}\right.$ and $\left.100^{\circ} \mathrm{C}\right)$ and $\mathrm{pH}$ values $(4.2$ and 9.2$)$ were used to leach the pots. The $\mathrm{pH}$ of the raw clays ranges from 2.08-6.50. The order of concentrations is $\mathrm{Fe}>\mathrm{Mn}>\mathrm{Pb}>\mathrm{Zn}>\mathrm{Ni}>\mathrm{Cr}>\mathrm{Cu}>\mathrm{Cd}$ for both clays and this was consistent with the XRF data. The results from this study indicate that $\mathrm{Cd}, \mathrm{Cr}, \mathrm{Cu}$ and $\mathrm{Pb}$ were not in leachable forms in clay pots. The clay pots indicated varying leachability for $\mathrm{Fe}$ and $\mathrm{Mn}$. The concentration ranges of $\mathrm{Fe}$ and $\mathrm{Mn}$ leached were 0.16-8.37 ppm and 0.08-10.00 ppm, respectively. In all cases the Kono-Boue pots indicated more leached concentrations of metals than Ara-Ekiti pots. It is essential to assess traditional clay pots for leachability of xenobiotics.
\end{abstract}

Keywords: Ara-Ekiti; Kono-Boue; Clay; Clay pot; Leaching; Metals

\section{Introduction}

Food and Drug Administration (FDA) compliance programs are not available in most developing countries. Consequently records of toxic elements in food and foodwares are not known to consumers in most countries in Africa. In Nigeria and some other African countries foodwares produced from local clay materials are still very popular. In some of these countries big and popular restaurants and eateries sited major towns advertise the use of local clay based foodware in preparation and serving of meals. Improperly formulated, or fired clay based foodwares may permit unacceptable amounts of toxic elements to leach into food or portable water. Therefore the need to evaluate raw clay employed for clay based foodwares and finished clay based pottery products cannot be over emphasized. Presently, even in some developed countries there are no validated protocols tests for detecting toxic metals in foodwares.

The Council of Europe committee of experts on materials coming into contact with food and the committee of experts on nutrition, food safety and consumer health, and other committees in public health field in justifying their guidelines on metals and alloys used as food contact materials suggested that these materials can migrate into foodstuff and could endanger human health if the total content of these metals exceeds recommended exposure limits (Council of Europe, 2002). The guideline associated with nutrition deals with elements from migration point of view and considers same as contaminants, even with essential elements. However, These Guidelines (Article 2.2 of Directive 89/109/EEC) are not legally binding but are considered by the member states as a reference document. Metals covered in the guidelines include, Aluminium, Chromium, Copper, Iron, Lead,
Manganese, Nickel, Silver, Tin, Titanium, Zinc, Cadmium, Cobalt and Mercury.

In Nigeria, the clay pottery industry is small-scale and widespread due to the distribution of clay deposits in over eighty (80) different locations [1]. Food processing and storage of portable water in locally made clay pots are common all over the country. For instance, the Kono-Boue and Ara-Ekiti Communities of Rivers State, South-South Nigeria and Ekiti State, South-West Nigeria, respectively, are among the several locations in Nigeria where clay is mined and used for pottery making. Previous studies have indicated that the constituents and properties of clay soils and clay based products vary from one geographical location to another [2,3]. Therefore leachability of the constituent elements may also vary for different locations. Consequently, studies are needed to evaluate the elemental constituents and the associated leachabilities of clays deposits and foodware products made from them. The aim of this study is to evaluate the elemental constituent of two different clay deposits in Nigeria and assess their suitability as food and portable water contact materials.

\section{Materials and Methods}

\section{Sample collection and pre-treatment}

A total of 3 clay deposit samples were collected at a depth of about 1 $\mathrm{m}$ with soil auger from sites across each of the clay deposit sites at Kono-Boue in Rivers State, South-South Nigeria (KBC) and Ara-Ekiti in Ekiti State, South-West Nigeria (AEC) (Figure 1). Clay pot samples produced from Kono-Boue (KBCP) and Ara-Ekiti (AECP) were purchased from potters producing with clay mined from the respective locations. All the samples were labeled accordingly and transported to Chemistry Department Laboratory of the Rivers State University 
(RSU), Port Harcourt. The clay soil samples spread in plastic trays allowed to dry in the laboratory. The air-dried clay samples were disaggregated and sieved using a $2 \mathrm{~mm}$ stainless sieve screen. The clay pots were broken into small piece units and then ground in porcelain mortar before sieving with $2 \mathrm{~mm}$ sieve. The $<2 \mathrm{~mm}$ clay and clay pot samples transferred into labeled poly ethylene bags and stored at room temperature for treatment and analysis.

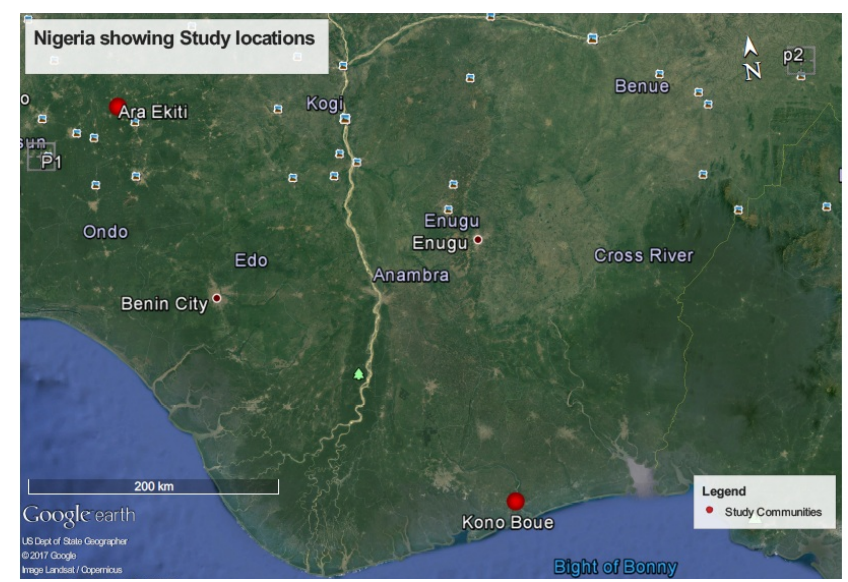

Figure 1: Map of the study area showing the locations of clay deposits.

\section{Sample treatment}

Determination of $\mathrm{pH}$ : The $\mathrm{pH}$ of the samples was determined in $\mathrm{CaCl}_{2}$ solution and deionized water. About $10 \mathrm{~g}$ of the $<2 \mathrm{~mm}$ soil samples were weighed into bottles with screw caps and $25 \mathrm{ml}$ of water was added and the bottle capped. The resulting suspension was shaken to mix for 15 mins period. The cap of the bottle was removed and the $\mathrm{pH}$ meter electrode inserted and $\mathrm{pH}$ reading recorded. The same procedure was conducted with $\mathrm{CaCl}_{2}$ solution instead in place of water.

\section{Sample digestion}

A $0.5 \mathrm{~g}$ of each of the samples was accurately weighed and transferred into a boiling test tube. Thereafter, $20 \mathrm{ml}$ of aqua regia (Nitric acid: Hydrochloric acid, ratio 1:3) was added to each sample. These procedures were carried out in triplicates. A blank solution was prepared by measuring $20 \mathrm{ml}$ of aqua regia only into the boiling tubes in order to evaluate the contribution of acid medium in the analysis. The mixture was heated to boiling in a fume-cupboard for 1 hour 30 mins. The resulting digests were allowed to cool and filtered into $50 \mathrm{ml}$ flask in the fume cupboard. The filtrate was made to mark with deionized water and preserved for analysis.

\section{Leaching tests}

Leaching tests were conducted to determine the migration of heavy metals from Kono-Boue Clay Pot (KBCP) and Ara-Ekiti Clay Pot (AECP) into the food and water stored therein. Ordinary tap water and simulated food methods were used to conduct the leaching test.

\section{Leaching with tap water}

The clay pots were filled with ordinary tap water to about $90 \%$ of its capacity and allowed to stand on a tripod stand for 12 hours at room temperature. Thereafter, the water was filtered and stored in polyethylene bottles for further analysis. Part of the tap water not used for the leaching test was preserved for analysis as blank.

\section{Leaching in simulated food}

Leaching of heavy metals in clay pots by simulated food method was carried out according to ASTM 738-94 standard test method for specific metals leaching into $4 \%$ Acetic acid solutions at varying temperatures and $\mathrm{pH}$ values. $\mathrm{A} \mathrm{pH}$ of 4.2 was adopted for acidic conditions that are likely to occur in foodstuffs, such as canned tomatoes. In recent studies, researchers have shown that leaching of metals into 4\% Acetic acid solution occur similar to the manner in which leaching occurs when preparing foodstuffs of about $\mathrm{pH}$ 4.2. A $\mathrm{pH}$ of 9.2 adopted to mimic the alkaline conditions in some foodstuffs. Leaching solutions (ordinary tap water) of $\mathrm{pH} 4.2$ and 9.2, at ambient temperature $\left(28^{\circ} \mathrm{C}\right.$ ), and at about $100^{\circ} \mathrm{C}$, were each exposed to the clay pots for 1 hour. The resulting leachates were filtered and stored in polyethylene bottles for further analysis.

\section{Heavy metals analysis}

The migrated heavy metals from the clay pot samples were determined using Flame Atomic Absorption Spectrophotometer (FAAS) (Releigh WFX 320 model). For quality assurance and quality control, blank solutions of the ordinary water were analyzed for heavy metal concentration.

\section{Wavelength dispersive $\mathrm{X}$-ray fluorescence analysis of clays}

Details of the principle and instrumentation of the wavelength dispersive X-ray fluorescence has been previously reported by Krishna [4]. In this study samples were pulverized to fine homogeneous size and then pelletized and submitted for quantitative elemental analysis of the clays and clay pots using EDX 3600B Energy Dispersive X-ray Fluorescence (EDXRF) spectrometer (Skyray Instrument Ltd, China) at the NASENI Centre of Excellence, Nanotechnology and Advanced Materials, Akure.

\section{Experimental quality control}

Analytical accuracy of aqua regia extractions were assessed against a reference material, BCR 143R (aqua regia certified Sewage sludge amended soil). All digestions were repeated three times. Excellent results were obtained for total concentrations; Cd measured was $69.0 \pm$ $1.9 \mathrm{mg} / \mathrm{kg}$ compared to the certified value of $72.0 \pm 1.8 \mathrm{mg} / \mathrm{kg}$. Cu measured was $119.0 \pm 5.3 \mathrm{mg} / \mathrm{kg}$ compared to the certified value of $130.6 \pm 1.5 \mathrm{mg} / \mathrm{kg}$. Pb measured was $187 \pm 9.0 \mathrm{mg} / \mathrm{kg}$ compared to the certified value of $174 \pm 5.0 \mathrm{mg} / \mathrm{kg}$. Mn measured was $834 \pm 18 \mathrm{mg} / \mathrm{kg}$ compared to the certified value of $858 \pm 11 \mathrm{mg} / \mathrm{kg}$. Zn measured was $1050 \pm 39 \mathrm{mg} / \mathrm{kg}$ compared to the certified value of $1063 \pm 16 \mathrm{mg} / \mathrm{kg}$. $\mathrm{Ni}$ measured was $277 \pm 19 \mathrm{mg} / \mathrm{kg}$ compared to the certified value of $299 \pm 5 \mathrm{mg} / \mathrm{kg}$. There were no listed values for $\mathrm{Cr}$ and $\mathrm{Fe}$.

AAS was calibrated using at least 6 standards of all the elements of interest (AccuTrace Reference Standard-AA29N-1) obtained from AccuStandard, Inc, USA. After every ten (10) measurements a standard was also analysed to avoid bias. The instrument was recalibrated before use any other day. The AAS limits of quantification 
were $0.8,3.0,1.5,5.0,1.5$ 6.0, 15.0 and $1.5 \mu \mathrm{g} / \mathrm{L}$ for $\mathrm{Cd}, \mathrm{Cr}, \mathrm{Cu}, \mathrm{Fe}, \mathrm{Mn}$, $\mathrm{Ni}, \mathrm{Pb}$ and $\mathrm{Zn}$, respectively.

\section{Results and Discussion}

\section{$\mathrm{pH}$ of clays and related clay pottery}

The $\mathrm{pH}$ values of the clay soil and their related clay pot samples, $\mathrm{AEC}, \mathrm{AECP}, \mathrm{KBC}$ and $\mathrm{KBCP}$ in water solution and in $\mathrm{CaCl}_{2}$ solution are as presented in Table 1. The $\mathrm{pH}$ values, $6.50 \pm 0.03$ and $5.77 \pm 0.11$ obtained for Ara-Ekiti Clay sample in water and $\mathrm{CaCl}_{2}$ solution are within the range, 4.8-6.9 reported for Nigerian soils by $\mathrm{Abu}$ and Nwosu [5] and Raji and Mohammed [6]. The pH values, $2.22 \pm 0.07$ and 2.08 \pm 0.14 obtained for Kono-Boue Clay sample in water and $\mathrm{CaCl}_{2}$ solution are outside the range previously reported for Nigerian soils. The Kono-Boue Clay indicated very low $\mathrm{pH}$ values that fail under a class called the ultra-acidic soils. The exceptionally low $\mathrm{pH}$ values observed the Kono-Boue Clay deposit is strange. However, a recent study by Obi [7] that surveyed the effect of gas flare on soil $\mathrm{pH}$ in selected communities in Niger Delta of Nigeria found that the $\mathrm{pH}$ changed from extremely acidic (3.5-4.4) to moderately alkaline (7.9-8.4) as they moved away from the flare points. The clay deposit site at Kono-Boue is close to a gas flare facility; therefore the extreme acidity of the clay from this site may have been induced by the close gas flare facility.

Lower $\mathrm{pH}$ values of $5.20 \pm 0.03$ and $4.33 \pm 0.14$ were obtained for Ara-Ekiti Clay Pot sample in water and $\mathrm{CaCl}_{2}$ solution respectively. Higher $\mathrm{pH}$ values of $4.18 \pm 0.21$ and $3.88 \pm 0.06$ were obtained for Kono-Boue Clay Pot sample in water and $\mathrm{CaCl}_{2}$ solution respectively. The relative decreased and increased $\mathrm{pH}$ ranges obtained from the Ara-Ekiti Clay Pot and the Kono-Boue Clay Pot respectively may have resulted during firing stage of processing the raw clay samples [8] into pottery.

\begin{tabular}{|l|l|l|}
\hline \multirow{2}{*}{ Sample ID } & \multicolumn{2}{|l|}{ pH values } \\
\cline { 2 - 3 } & Water & $\mathrm{CaCl}_{2}$ solution \\
\hline AEC & $6.50 \pm 0.03$ & $5.77 \pm 0.11$ \\
\hline AECP & $5.20 \pm 0.03$ & $4.33 \pm 0.14$ \\
\hline KBC & $2.22 \pm 0.07$ & $2.08 \pm 0.14$ \\
\hline KBCP & $4.18 \pm 0.21$ & $3.88 \pm 0.06$ \\
\hline
\end{tabular}

Table 1: Mean and standard deviation of $\mathrm{pH}$ of Ara-Ekiti and KonoBoue Clay and related Clay Pots in deionized water and $\mathrm{CaCl}_{2}$ solution.

Where, AEC=Ara-Ekiti Clay; AECP=Ara-Ekiti Clay Pot; $\mathrm{KBC}=$ Kono-Boue Clay;

\section{Heavy metal concentration clay soils and clay pot samples}

The concentrations of $\mathrm{Cu}, \mathrm{Ni}, \mathrm{Pb}, \mathrm{Cd}, \mathrm{Mn}, \mathrm{Fe}, \mathrm{Cr}$ and $\mathrm{Zn}$ obtained from the clay soil and clay pots following acid digestion of samples are provided in Table 2. The order of concentrations is $\mathrm{Fe}>\mathrm{Mn}>\mathrm{Pb}>\mathrm{Zn}>\mathrm{Ni}>\mathrm{Cr}>\mathrm{Cu}>\mathrm{Cd}$ for Ara-Ekiti Clay, Kono-Boue Clay and the Ara-Ekiti Clay Pot (Table 2) and this order is consistent with elemental data previously published by Omoniyi [9] and Gbarakoro [3]. The mean concentrations observed in this for $\mathrm{Ni}, 77.67 \mathrm{ppm}, \mathrm{Pb}$, 135.27 and $\mathrm{Zn}, 93.17 \mathrm{ppm}$ are within the range of concentrations of $\mathrm{Ni}$,
88-290 ppm, Pb, 75-310 ppm and Zn, 88-290 ppm, previously reported for Ara-Ekiti Clay deposits by Omoniyi [9]. The order of concentrations, $\mathrm{Fe}>\mathrm{Mn}>\mathrm{Zn}>\mathrm{Pb}>\mathrm{Ni}>\mathrm{Cr}>\mathrm{Cu}>\mathrm{Cd}$ for Kono-Boue Clay Pot is different compared to that of Ara-Ekiti Clay Pot, consistent with previous EDX elemental composition count data on Kono-Boue Clay by Gbarakoro [3]. The presence and elevated levels of the metals in clay deposits and enamels for ceramics have been highlighted in previous studies [10-14]. The presence of the potentially toxic metals, $\mathrm{Cd}, \mathrm{Cr}$, $\mathrm{Cu}, \mathrm{Fe}, \mathrm{Mn}, \mathrm{Ni}, \mathrm{Pb}$ and $\mathrm{Zn}$ is also confirmed by the metal peaks indicated on XRF analysis results Ara-Ekiti (Figure 2) and Kono-Boue (Figure 3) clays. The trend of concentration loading observed from the AAS analysis of the acid digest (Table 2) is consistent with the trend indicated in the XRF results (Figures 2 and 3).

The relative increase in the heavy metal content of the clay pots compared to the raw clay sample may have resulted from additives that are added during clay pot production. At elevated firing temperatures, of $1300-1600^{\circ} \mathrm{C}$ employed for pottery production, there is increase in bulk density values of fired clay samples, resulting in corresponding increase in concentration of the heavy metals and decreased porosity of the clay pot. With decreased porosity, the thermal conductivity values of fired samples increased and vice versa.

\begin{tabular}{|c|c|c|c|c|c|c|c|c|}
\hline \multirow{2}{*}{$\begin{array}{l}\text { Sampl } \\
\text { es }\end{array}$} & \multicolumn{8}{|c|}{ Heavy Metals Concentration (mg/kg) } \\
\hline & $\mathrm{Cr}$ & Cd & $\mathbf{N i}$ & $\mathrm{Cu}$ & $\mathrm{Zn}$ & $\mathrm{Fe}$ & $\mathrm{Pb}$ & Mn \\
\hline AEC & $\begin{array}{l}69.77 \\
\pm 6.55\end{array}$ & $\begin{array}{l}6.4 \pm \\
1.56\end{array}$ & $\begin{array}{l}77.67 \\
\pm 11.49\end{array}$ & $\begin{array}{l}17.2 \\
\pm \\
2.30\end{array}$ & $\begin{array}{l}93.17 \\
\pm 6.85\end{array}$ & $\begin{array}{l}3095 \pm \\
27.00\end{array}$ & $\begin{array}{l}135.27 \\
\pm \\
48.44\end{array}$ & $\begin{array}{l}417.47 \\
\pm \\
66.37\end{array}$ \\
\hline AECP & $\begin{array}{l}76.27 \\
\pm \\
11.37\end{array}$ & $\begin{array}{l}8.57 \\
\pm \\
2.31\end{array}$ & $\begin{array}{l}101.57 \\
\pm 8.27\end{array}$ & $\begin{array}{l}43.13 \\
\pm \\
1.72\end{array}$ & $\begin{array}{l}113.0 \\
3 \quad \pm \\
4.88\end{array}$ & $\begin{array}{l}1202.33 \\
\pm 24.05\end{array}$ & $\begin{array}{l}238.77 \\
\pm \\
46.21\end{array}$ & $\begin{array}{l}447.73 \\
\pm \\
60.71\end{array}$ \\
\hline KBC & $\begin{array}{l}71.93 \\
\pm 8.25\end{array}$ & $\begin{array}{l}14.5 \\
\pm \\
4.39\end{array}$ & $\begin{array}{l}97.53 \\
\pm 2.31\end{array}$ & $\begin{array}{l}31.2 \\
\pm \\
0.00\end{array}$ & $\begin{array}{l}136.9 \\
3 \pm \\
9.79\end{array}$ & $\begin{array}{l}2022.67 \\
\pm \\
149.72\end{array}$ & $\begin{array}{l}194 \pm \\
9.69\end{array}$ & $\begin{array}{l}354.5 \\
\pm \\
28.01\end{array}$ \\
\hline KBCP & $\begin{array}{l}52.27 \\
\pm 6.81\end{array}$ & $\begin{array}{l}9.9 \pm \\
0.00\end{array}$ & $\begin{array}{l}72.37 \\
\pm 9.45\end{array}$ & $\begin{array}{l}33.07 \\
\pm \\
9.45\end{array}$ & $\begin{array}{l}164.3 \\
3 \quad \pm \\
5.60\end{array}$ & $\begin{array}{l}2280.67 \\
\pm 92.38\end{array}$ & $\begin{array}{l}118.5 \\
\pm \\
42.28\end{array}$ & $\begin{array}{l}212.4 \\
\pm \\
70.73\end{array}$ \\
\hline
\end{tabular}

Table 2: Mean and standard deviation of heavy metals concentration in Ara-Ekiti and Kono-Boue Clay and related Clay Pots.

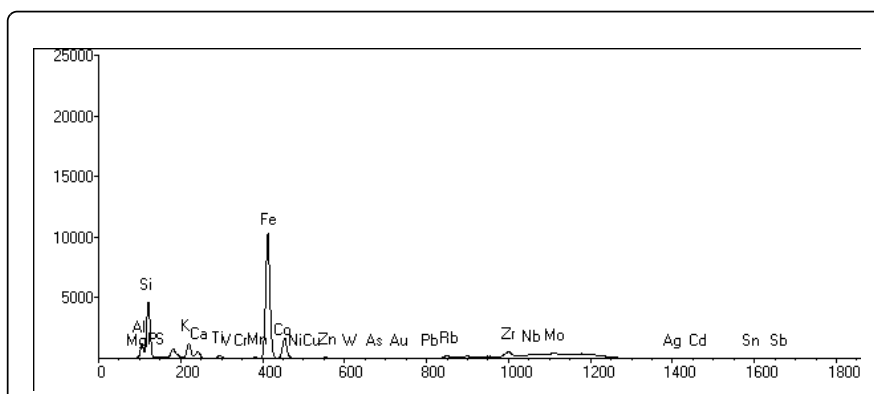

Figure 2: XRF analysis result for Ara-Ekiti Clay. 


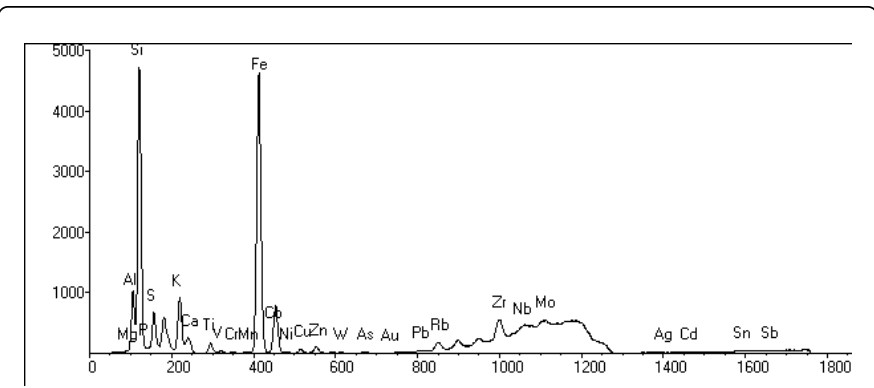

Figure 3: XRF analysis result of Kono-Boue Clay.

\section{Determination of potentially toxic metals leaching}

In order to simulate conditions of storage and cooking of both acidic and alkaline recipes the leaching test were conducted by exposing the clay pots to tap water at room temperature and at $100^{\circ} \mathrm{C}$ at $\mathrm{pH}$ of neutral (7.0), acidic (4.2) and alkaline (9.2). The results from this study indicate that $\mathrm{Cd}, \mathrm{Cr}, \mathrm{Cu}$ and $\mathrm{Pb}$ were not in leachable forms in the Ara-Ekiti and Kono-Boue Clay Pots and the poor leachability of certain metals from foodwares has previously been reported by Anderson and Aderemi [13,14]. The non leachability of $\mathrm{Cd}, \mathrm{Cr}, \mathrm{Cu}$, and $\mathrm{Pb}$ from the clays even at increased temperatures and $\mathrm{pH}$ conditions has previously been highlighted in adsorptions employing the Kono-Boue Clays for removal of $\mathrm{Cr}$ and $\mathrm{Pb}$ from water by Ajemba [15].

In both clay pots (Ara-Ekiti and Kono-Boue) $\mathrm{Ni}$ was highly nonleachable at neutral and alkaline $\mathrm{pH}$ values. Only minimal amount of $\mathrm{Ni}$ was leached from Kono-Boue Clay Pots at $\mathrm{pH} 4.2$ when the water was at $100^{\circ} \mathrm{C}$ and room temperature. It is possible that most of the $\mathrm{Ni}$ in the Ara-Ekiti Clay Pot are not leachable since Ara-Ekiti Clay soil indicated higher $\mathrm{pH}$, because soil $\mathrm{pH}$-dependent retention of $\mathrm{Ni}$ have previously been suggested by Mcbride and Lasiask [16]. Leaching test for $\mathrm{Zn}$ indicated very low migration of $\mathrm{Zn}(<0.13 \mathrm{ppm})$ from the AraEkiti Clay Pots irrespective of the $\mathrm{pH}$ and temperature changes. The low leachability of $\mathrm{Zn}$ may be indicative of the fact that the $\mathrm{Zn}$ mineral(s) in the Ara-Ekiti samples are insoluble in water. The KonoBoue however indicated higher but inconsistent order of leachability. The inconsistent order of leachability exhibited by the Kono-Boue samples is strange, but Jurinak and Thorne [17] had previously highlighted similar pattern of leachability for $\mathrm{Zn}$.
The concentrations of Fe leached upon exposure of Ara-Ekiti Clay Pot to water of neutral $\mathrm{pH}$, alkaline $\mathrm{pH}$ and acidic $\mathrm{pH}$ were $0.16 \mathrm{ppm}$, $0.08 \mathrm{ppm}$ and $1.15 \mathrm{ppm}$ at room temperature, and $0.19 \mathrm{ppm}, 0.16 \mathrm{ppm}$ and $5.33 \mathrm{ppm}$ at $100^{\circ} \mathrm{C}$, respectively. The concentrations of Fe leached upon exposure of Kono-Boue Clay Pot to water of neutral $\mathrm{pH}$, alkaline $\mathrm{pH}$ and acidic $\mathrm{pH}$ were $0.33 \mathrm{ppm}, 0.41 \mathrm{ppm}$ and $2.54 \mathrm{ppm}$ at room temperature, and $0.28 \mathrm{ppm}, 0.41 \mathrm{ppm}$ and $8.37 \mathrm{ppm}$ at $100^{\circ} \mathrm{C}$, respectively (Table 3 ). In both pots (Ara-Ekiti and Kono-Boue) the trend of leachability indicates a $\mathrm{pH}$ dependence tap on water's ability to leach Fe. Leaching test at neutral, alkaline and acidic conditions have indicated more Fe migration of from Kono-Boue Clay Pots into the tap water in spite of the lower Fe total concentration (Table 2) in the KonoBoue Clay. The higher leachability of Fe from the Kono-Boue Clay Pots compared to that of Ara-Ekiti Clay Pots is similar to the trend observed for acidity of raw clay employed for their production. The relatively higher availability of Fe from the Kono-Boue Clay Pots also agrees with our earlier suggestion that some fractions metals in the Kono-Boue Clays may have been contributed by human activities around the deposit site. The long time use of Kono-Boue Clay Pots for storage of food and drinking water, cooking of food and serving of cooked food may be a source Fe excessive introduction into human systemic circulation.

The concentrations of Mn leached upon exposure of Ara-Ekiti Clay Pot to water of neutral $\mathrm{pH}$, alkaline $\mathrm{pH}$ and acidic $\mathrm{pH}$ were $0.00 \mathrm{ppm}$, $0.08 \mathrm{ppm}$ and $0.15 \mathrm{ppm}$ at room temperature, and $0.00 \mathrm{ppm}, 0.09 \mathrm{ppm}$ and $0.75 \mathrm{ppm}$ at $100^{\circ} \mathrm{C}$, respectively. The concentrations of $\mathrm{Mn}$ leached upon exposure of Kono-Boue Clay Pot to water of neutral $\mathrm{pH}$, alkaline $\mathrm{pH}$ and acidic $\mathrm{pH}$ were $2.19 \mathrm{ppm}, 0.67 \mathrm{ppm}$ and $6.00 \mathrm{ppm}$ at room temperature, and $0.14 \mathrm{ppm}, 0.35 \mathrm{ppm}$ and $10.00 \mathrm{ppm}$ at $100^{\circ} \mathrm{C}$, respectively (Table 3 ). In both pots (Ara-Ekiti and Kono-Boue) the trend of leachability indicates a temperature and $\mathrm{pH}$ dependence on tap water's ability to leach Mn. Leaching test at neutral, alkaline and acidic conditions have indicated more Mn migration of from KonoBoue Clay Pots into the tap water in spite of the lower Mn total concentration (Table 2) in the Kono-Boue Clay. The relatively higher availability of $\mathrm{Mn}$ from the Kono-Boue Clay Pots also agrees with our earlier suggestion that some fractions metals in the Kono-Boue Clays not in mineral form but may have adhered to clay surfaces by weaker bonds. The long time use of Kono-Boue Clay Pots for storage of food and drinking water, cooking of food and serving of cooked food may be a source $\mathrm{Mn}$ excessive introduction into human systemic circulation.

\begin{tabular}{|c|c|c|c|c|c|c|c|}
\hline \multirow[b]{2}{*}{ Metal } & \multirow[b]{2}{*}{ Clay Pot } & \multicolumn{6}{|c|}{ Leaching Test Conditions of Tap water } \\
\hline & & RM & RM (pH 4.2) & $\mathrm{RM}(\mathrm{pH}$ 9.2) & $100^{\circ} \mathrm{C}$ & $100^{\circ} \mathrm{C}(\mathrm{pH} 4.2)$ & $100^{\circ} \mathrm{C}(\mathrm{pH} 9.2)$ \\
\hline \multirow[t]{2}{*}{$\mathrm{Cd}$} & AECP & ND & ND & ND & ND & ND & ND \\
\hline & KBCP & ND & ND & ND & ND & ND & ND \\
\hline \multirow[t]{2}{*}{$\mathrm{Cr}$} & AECP & ND & ND & ND & ND & ND & ND \\
\hline & KBCP & ND & ND & ND & ND & ND & ND \\
\hline \multirow[t]{2}{*}{$\mathrm{Cu}$} & AECP & ND & ND & ND & ND & ND & ND \\
\hline & KBCP & ND & ND & ND & ND & ND & ND \\
\hline $\mathrm{Fe}$ & AECP & 0.16 & 1.15 & 0.08 & 0.33 & 2.54 & 0.28 \\
\hline
\end{tabular}


Page 5 of 5

\begin{tabular}{|c|c|c|c|c|c|c|c|}
\hline & KBCP & 0.19 & 5.33 & 0.16 & 0.49 & 8.37 & 0.41 \\
\hline \multirow[t]{2}{*}{$\mathrm{Mn}$} & AECP & ND & 0.15 & 0.08 & ND & 0.75 & 0.09 \\
\hline & KBCP & 2.19 & 6 & 0.67 & 0.14 & 10 & 0.35 \\
\hline \multirow[t]{2}{*}{$\mathrm{Ni}$} & AECP & ND & ND & ND & ND & ND & ND \\
\hline & KBCP & ND & 0.07 & ND & ND & 0.23 & ND \\
\hline \multirow[t]{2}{*}{$\mathrm{Pb}$} & AECP & ND & ND & ND & ND & ND & ND \\
\hline & KBCP & ND & ND & ND & ND & ND & ND \\
\hline \multirow[t]{2}{*}{$\mathrm{Zn}$} & AECP & 0.03 & 0.01 & 0.03 & 0.07 & 0.13 & 0.05 \\
\hline & KBCP & 0.05 & 0.21 & 0.08 & 1.71 & 0.47 & 0.05 \\
\hline
\end{tabular}

Table 3: Leached heavy metal concentration (ppm) from Ara-Ekiti and Kono-Boue Clay Pots at varying conditions of $\mathrm{pH}$ and temperature.

Where, ND-Not detected; RM-Room Temperature; AECP-Ara-Ekiti Clay Pot; KBCP-Kono-Boue Clay Pot.

\section{Conclusion}

This study has demonstrated the presence of $\mathrm{Cd}, \mathrm{Cr}, \mathrm{Cu}, \mathrm{Mn}, \mathrm{Ni}, \mathrm{Pb}$, $\mathrm{Zn}$ and elevated total concentrations of $\mathrm{Fe}$ in raw clays mined for clay pottery and clay pots in Ara-Ekiti and Kono-Boue of Nigeria. Whilst it is typical in the spirit of preserving culture to promote the continued used of traditional foodwares at homes and public eateries, this study highlights the possibility of undesirable leaching of potentially toxic metals from the traditional foodwares into food. At conditions mimicking food preparation and storage detectable concentrations of $\mathrm{Fe}, \mathrm{Mn}$ and $\mathrm{Zn}$ leached from the clay pots into extraction media. The risk of taking up $\mathrm{Fe}, \mathrm{Mn}$ and $\mathrm{Zn}$ when traditional clay pots are used to prepare food has been highlighted. Whilst these data do not prove a direct causal link, possibility of leaching out Fe, Mn and $\mathrm{Zn}$ from these traditional clay pots clearly demonstrates the need for foodware products quality control agencies in developing countries to put up strategies to eliminate or minimize undesirable of potentially toxic metal from clay based foodwares.

\section{Acknowledgement}

This work on leachability of potentially toxic metals from traditional clay pots forms part of D. Bekee's M.Sc Studentship at the Rivers State University, Port Harcourt. The authors would like to thank Mr. Ofiwe Collins Uche (NASENI Centre of Excellence, Nanotechnology and Advanced Materials, Akure) for the XRF analysis.

\section{References}

1. Alege TS, Idakwa SO, Alege EK, Gideon YB (2004) Geology, Mineralogy and Geochemistry of Clay Occurrences within the Northern Anambra Basin, Nigeria. British Journal of Applied Science and Technology 4: 841-852.

2. Amponsah-Dacosta F, Muzerengi C, Mholongo SE, Mukwevho GF (2013) Characterization of clays for making ceramic pots and water filters at Mukondeni Village, Limpopo Province, South Africa. ARPN Journal of Engineering and Applied Science 8: 927-932.

3. Gbarakoro SL, Konne JL, Boisa N (2016) Characterization of Kono-Boue Clay as Possible Catalyst for Biodiesel Production. International Journal of Science and Research 5: 924-928.
4. Krishna K, Murthy N, Govil PK (2007) Multielement Analysis of Soils by Wavelength-Dispersive X-ray Fluorescence Spectrometry. Atomic Spectroscopy-Norwalk Connecticut 28: 202.

5. Abii TA, Nwosu PC (2009) The Effect of Oil-Spillage on the Soil of Eleme in Rivers State of the Niger-Delta Area of Nigeria. Research Journal of Environmental Sciences 3: 316-320.

6. Raji BA, Mohammed K (2000) The nature of acidity in Nigerian savanna soils. Samaru Journal of Agricultural Research 16: 15-24.

7. Obi EO, Osang JE, Pekene DB (2016) Environmental Effect of Gas Flaring on the Soil pH Value in Some Communities in Niger Delta of Nigeria. American Journal of Physics and Applications 4: 158-164.

8. Gosselain OP (1992) Technology and Style: Potters and Pottery Among Bafia of Cameroon. Man 27: 559-586.

9. Omoniyi IM, Oludare SMB, Oderinde O (2013) Determination of radionuclides and elemental composition of clay soils by gamma-and $\mathrm{X}$ ray spectrometry. Springer Plus 2: 74 .

10. Schnaas L, Rothenberg SJ, Flores MF, Martínez S, Hernández C, et al. (2004) Blood Lead Secular Trend in a Cohort of Children in Mexico City (1987-2002). Environmental Health Perspectives 112: 1110.

11. de la Campa AMS, de la Rosa JD, González-Castanedo Y, FernándezCamacho R, Alastuey A, et al. (2010) High concentrations of heavy metals in PM from ceramic factories of Southern Spain. Atmospheric Research 96: 633-644.

12. Liao QL, Liu C, Wu HY, Jin Y, Hua M, et al. (2015) Association of soil cadmium contamination with ceramic industry: A case study in a Chinese town. Science of the Total Environment 514: 26-32.

13. Anderson GL, Garnick L, Fung MS, Gaffney SH (2017) A pilot study to assess lead exposure from routine consumption of coffee and tea from ceramic mugs: comparison to California Safe Harbor Levels. International Journal of Food Contamination, Vol. 4.

14. Aderemi TA, Adenuga AA, Oyekunle JAO, Ogunfowokan AO (2017) High level leaching of heavy metals from colorful ceramic foodwares: a potential risk to human. Environmental Science and Pollution Research 24: 17116-17126.

15. Ajemba RO (2014) Kinetics and equilibrium modeling of lead (II) and chromium (III) ions' adsorption onto clay from Kono-bowe, Nigeria. Turkish Journal of Engineering and Environmental Sciences 38: 455-479.

16. Mcbride MB, Blasiak JJ (1979) Zinc and Copper Solubility as a Function of $\mathrm{pH}$ in an Acid Soil. Soil Science Society of America Journal 43: 866-870.

17. Jurinak JJ, Thorne DW (1955) Zinc Solubility Under Alkaline Conditions in a Zinc-Bentonite System. Soil Science Society of America Journal 19: 446-448. 